\title{
KAT6A Gene
}

National Cancer Institute

\section{Source}

National Cancer Institute. KAT6A Gene. NCI Thesaurus. Code C71429.

This gene is involved in both histone acetylation and transcriptional regulation. 